\title{
THE CIRCULAR PATH OF SOCIAL SUSTAINABILITY: AN EMPIRICAL
}

\section{ANALYSIS}

\begin{abstract}
The sustainable human resource management literature provides arguments linking the social sustainability dimensions of business and society, suggesting a circular or two-way relationship between them. The norm of reciprocity builds social sustainability by increasing trust and cooperation in any group of people and explains this complex relationship. In this study, we test the connection between society—-poverty and inequality—and business - human resource investment strategy — using a large longitudinal data set with six time points. Findings showed that past poverty negatively contributes to a later investment human resource strategy and vice versa. This mutual relationship configures a positive feedback loop where environmental social sustainability and organizational social sustainability enhance each other. Results also show that investment human resource strategy negatively affects income inequality, revealing that corporate decisions on social sustainability can affect social sustainability of society.
\end{abstract}

Keywords: sustainable human resource management, social sustainability, business and society, longitudinal structural equation modeling. 


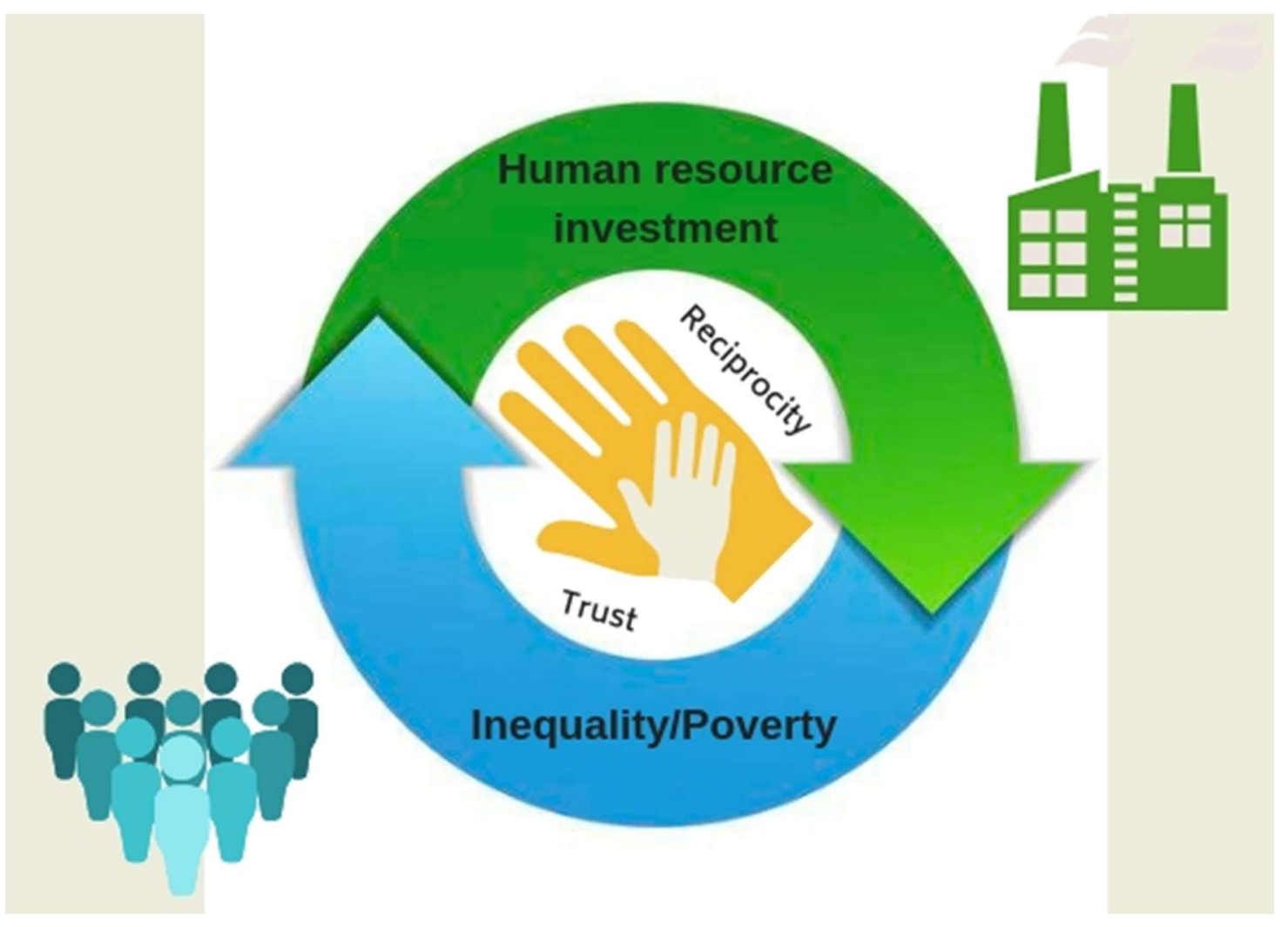




\section{INTRODUCTION}

Reducing countries' poverty and income inequality are two of the priority objectives of the 2030 Agenda for Sustainable Development, approved on September 25, 2015 by the General Assembly of the United Nations (UN). Poverty refers to certain deprivations or shortcomings suffered by people in a society that endanger their well-being (Bourguignon, 2004; Cobb, 2016). Poverty is manifested as the denial of the most fundamental opportunities and options for human development. Inequality refers to the disparity in the distribution of income among members of a society, which allows one group certain opportunities for human development while denying them to another (Cobb, 2016). Although the two concepts represent different and pernicious facets of the human or social dimension of a society's sustainable development (Florea et al., 2013; Hutchins \& Sutherland, 2008; Rogers et al., 2012; Sharma \& Ruud, 2003), they have received scarce attention in the sustainability literature, which mainly focuses on examining the physical or ecological dimensions of sustainability (Ajmal et al., 2017; Athanasopoulou \& Selsky, 2015; Hughes, et al., 2017; Pfeffer, 2010; Sharma \& Ruud, 2003).

Despite the positive proposals of UN, poverty and income inequality within developed countries, particularly among their different regions, have increased in recent years due to the economic crisis that began in 2008 (Cobb \&Stevens, 2017; Jiang \& Probst, 2017; Piacentini, 2014). The level and disparity of the income of the population in the geographic area in which an organization is located provides the context for the processes of social exchange between people. This circumstance therefore affects the organizational behavior of the companies located in that area and, at the same time, because employees and the organizations interact with other people and agents in that territory, organizational behavior can contribute to the socioeconomic development of that region (Leana \& Meuris, 2015). In other words, there is a bilateral or two-way relationship between society and business. Consequently, organizational 
research is needed to introduce the environment's socio-economic characteristics into the management debate (Bapuji, 2015; Cobb, 2016; Cobb \& Stevens, 2017, Leana \& Meuris, 2015), especially in the area of human resources management, which represents the social dimension of organizational sustainability (Hughes, et al., 2017; Pfeffer, 2010).

The marginalization and interpretative flexibility of social sustainability means that there is still no clear definition of this concept and its components, which recommends understanding it as a framework that can be used to communicate, make decisions, and assess progress (Boström, 2012; Broman and Robèrt, 2017; Peterson, 2016). This frame can be dynamic over time and encompass the identification of a variety of elements in different areas and how they can mutually influence one other (Peterson, 2016), including clearly defined ideas about what kinds of social values to promote (Boström, 2012). A common denominator of many investigations has been to highlight some essential ethical values, such as equity, trust, cooperation, justice, and fairness, as the heart of social sustainability (e.g., Ajmal et al., 2017, Boström, 2012; Čiegis et al., 2008; Jabbour, \& de Sousa Jabbour, 2016; Peterson, 2016). In this regard, a group of researchers integrated under the project "Framework for Strategic Sustainable Development" (Broman \& Robèrt, 2015; Missimer et al., 2017a, b) identify social trust as the central ethical value of social sustainability, therefore, understand how social trust is built is key to maintaining social sustainability, being necessary to examine the mechanisms that hinder (or favor) it and the possible interrelationship between them over time. Given that normally social sustainability has been examined at societal and organizational scopes (e.g., Ajmal et al., 2017; Missimer et al., 2017b), it would be especially important to study the potential mutual effect between elements located in these two areas.

The sustainable human resource management (HRM) literature explicitly recognizes this relationship of interdependence between society and companies' human resources strategies (e.g., Ehnert et al., 2014; 2016; Jabbour \& Santos, 2008; Kramar, 2014; Renwick et 
al., 2013). From this perspective, it is argued that the social dimension of society and the social dimension of the company influence and support each other, forming a circular relationship between them. However, most of the previous research is of a conceptual or merely exploratory nature (Ehnert et al., 2016; Macke \& Genari, 2019) and this link has been recognized only at a theoretical level, thus creating a need for empirical studies to corroborate its existence (Ehnert et al., 2016; Mariappanadar, 2014; Renwick et al., 2013). The purpose of this study is to contribute to bridging this gap by focusing on the social dimension of sustainability and analyzing the potential existence of a bidirectional relationship between poverty and income inequality in a society and the human resources strategy of the companies located in that society. In societal scope, poverty and income inequality are related to the lack of trust and in the organizational sphere the investment in human resources is associated with trust. Only through a better understanding of this relationship between business and society, we can make progress on the path toward social sustainability (Hutchins \& Sutherland, 2008). The empirical corroboration of this relationship would therefore represent a significant advance in the field of sustainable HRM.

From a methodological point of view, as a dynamic approach is necessary to examine the interdependence between society and business (Ehnert et al., 2014), we designed a longitudinal structural equation model that is capable of adequately representing a bidirectional causal relationship between two variables at different points in time (Little, 2013). More methodical and empirical efforts are required to continue understanding the cause-and-effect relationships between various social sustainability elements over time (Mesmer-Magnus et al., 2012; Rogers et al., 2012). Our empirical study is developed in the European context, 
specifically in Spain. As the European Commission underlines in its "ImPRovE" project ${ }^{1}$, sponsored by the European program "Horizon 2020", in Europe the economic crisis has not yet been overcome and is generating high poverty and inequality in the population of certain regions, considerably increasing the disparities between different geographical areas (Kis \& Gábos, 2015, Piacentini, 2014). Spain is an illustrative example of this circumstance, since the disparity between Spanish regions in terms of poverty and inequality is much greater at present (Ayala \& Jurado, 2015, Llano, 2017). This high divergence is a necessary condition for choosing a country as a territorial framework with the objective of examining the interrelation between society and business (Cobb \& Stevens, 2017).

\section{THEORETICAL FRAMEWORK}

\subsection{Social sustainability}

In 1987, the UN "World Commission on Environment and Development" produced the Brundtland Report, which defined sustainability as development capable of meeting the needs of the present without compromising the ability of future generations to satisfy your own needs. In this report, sustainability refers to the ability to sustain over time in three basic dimensions of a human system, namely, the protection of the environment, economic growth and social inclusion. These three pillars are generally assumed to be compatible and mutually supportive (Boström, 2012). Much of the debate on sustainability has been dominated by ecological and economic factors, so when sustainable development is supported, the social dimension attracts less attention and, as a result of this neglect, it is the least conceptually developed of the three pillars, being difficult to define and operationalize (Ajmal et al., 2017; Boström, 2012;

\footnotetext{
1 "Poverty Reduction in Europe: Social Policy and Innovation" (ImPRovE) is an international research project that brings together a broad network of researchers in a concerted effort to study poverty and social policy in Europe.
} 
Missimer et al., 2017a; Staniškienè \& Stankevičiūtè, 2018). A reflection of this ambiguity is the wide range of definitions of social sustainability that we find in the literature (Ajmal et al., 2017). Many of these definitions share that social sustainability is a quality of a human system that is based on a series of values or essential ethical principles (e.g., fairness, trust, equity, justice, cooperation, engagement) that foster lasting conditions for human well-being , particularly for those most vulnerable people or groups (e.g., Ajmal et al., 2017, Boström, 2012, Hollander et al., 2016, Sharma and Ruud, 2003). In that sense, social sustainability is not about a bounteous human life, but about satisfy the basic conditions that are necessary for the human system to not systematically degrade (Missimmer et al., 2017a),

Missimer et al., (2017a,b) observe social sustainability from a social system's perspective and identify trust as he preponderant value of a vital human system. "Trust is defined as an attitude that enables an agent to cope with situations of uncertainty and lack of control, by making themselves vulnerable based on positive expectations towards another agent, derived from the assessment of the trustworthiness of the trusted agent" (Missimer et al., 2017b; p. 46). Like all living systems, human social systems can be considered complex adaptive systems, and trust is seen as a quality of connection to deal with the risk and uncertainty inherent in this complexity. Also, trust allows coordinate the system in its adaptation and generate for collective action. It is no easy to conceive a sustainable social system without trust relationships, the basis of a cooperative behavior and the glue that connects the members of a social system, allowing the system to remain together. Social sustainability is about the elimination of mechanisms of systematic degradation of social trust (Missimer et al., (2017a,b). Following this perspective within the societal context, some definitions of social sustainability propose eliminating these mechanisms. Thus, for example, the 2030 Agenda for Sustainable Development emphasizes that the eradication of poverty is an indispensable condition for achieving sustainable development, in such a way that inclusive and equitable 
economic growth must be promoted, reducing inequalities between people. Impoverished and unequal societies are related to an absence of social trust (Haushofer \& Fehr, 2014; Missimer et al., 2017b, Wilkinson \& Pickett, 2010, 2017).

Within the business context, social trust are related to job security, health and safety, training and learning, wages that allow for a basic decent living, and professional growth (Missimer et al., 2017b). These core human resources management practices are in line with employee cooperation and involvement (Jabbbour \& de Sousa Jabbour, 2016) and with social exchange theory (Awan et al., 2018) largely underlined in the social sustainability literature. Social exchange theory adheres to the rules of mutual commitment between members in an organization and is established on the cultural values of trust and fairness that support cooperative behavior, in such a way that the granting of a benefit creates the obligation of reciprocate (Cropanzano \& Mitchell, 2005; Gouldner, 1960). Employee cooperation is a key component of social sustainability and enables reaching the synergy effect of sharing experiences with colleagues lead to members involvement (Staniškienė \& Stankevičiūtè, 2018). Grounded on social exchange theory and in supply chain context, Awan et al., (2018) suggest that social trust and cooperation are the basis for a relational governance in the buyer-supplier relationship, being regulated by shared norms of reciprocity that originate obligations for promote a mutual adjustment and joint action.

\subsection{Sustainable HRM}

As we explained above, the analysis of social sustainability leads us to observe society and organizations as intrinsically human entities, in which the attitudes and values that guide people's behavior drive the social transformations necessary to ensure human well-being. Some studies on sustainable HRM dealt with the link between human resources management and the social dimension of sustainability, especially with regard to organizational social responsibility, therefore, the principles of social sustainability are embedded in sustainable HRM (Macke and 
Genari, 2019). Sustainable HRM implies social norms that contemplate the ethical principles of loyalty, trust, mutual commitment and equity in labor relations and, therefore, stimulate sustainable individual and organizational behavior (Athanasopoulou \& Selsky; 2015; Gollan, 2005; Jabbour \& Santos, 2008). In this regard, authors such as Florea et al., (2013), Hutchins and Sutherland (2008) and Renwick et al., (2013) agree that the social dimension of organizational sustainability is based on the "norm of reciprocity" (Gouldner, 1960), which holds that people should help those who helped them and, thus, those you have helped have an obligation to help you. According to Gouldner (1960), this moral principle contributes to the long-term maintenance of any stable social group. The social norm of reciprocity is therefore associated with the universal ethical values of trust and cooperation, typical of the definition of sustainable development, applicable both in the sphere of organizations and in that of society.

In a poor and unequal society, the values of cooperation and trust on which reciprocal behavior is based are weakened (Jiang \& Probst, 2017; Leana \& Meuris, 2015; Pitesa et al., 2017; Wilkinson \& Pickett, 2010, 2017). Income inequality creates a more competitive and less cohesive social environment, and displaces us from social behavior characterized, at one extreme, by exchange and reciprocity, to social behavior characterized by individual interest and the dominant hierarchy. People are much more likely to feel that they can trust others in more equitable societies (Leana $\&$ Meuris, 2015). Similar to inequality, poverty is a precursor to the lack of trust among the members of a society (Pitesa et al., 2017). Those with scarce material resources (e.g., people who earn a minimum wage) and who may be below the poverty line established in a society have a lower capacity for trust, which in turn reduces reciprocity between members of a society. This decreased cooperation can cause social division, contribute to social stratification and reduce socioeconomic opportunities for people of all social groups (Pitesa et al., 2017). In short, the social values of trust and inclusion integrated into the concept 
of sustainable development are undermined in poor and unequal societies (Missimer et al., 2017b; Rogers et al., 2012, Sharma \& Ruud, 2003).

In the organizational sphere, the norm of reciprocity is reflected in the implementation of an HR investment strategy. Although the specific HR practices to be considered as part of an HR investment strategy vary among studies, many researchers agree that three main HR practices reflect firms' investments in their employees, namely, competitive remuneration, training and job security (e.g., Batt \& Colvin, 2011; Miller \& Lee, 2001; Roca-Puig et al., 2012,2018; Roh \& Kim, 2016; Subramony et al., 2008). These HR investments can be considered as inducements offered by the firm to its employees and are intended to send signals about high levels of employer commitment to all employees. Investing in employees is repaid in the form of employee commitment to the organization, and committed employees are more likely to engage in positive employee attitudes and extra-role behaviors (e.g., cooperation, trust and organizational citizenship behaviors), creating what Mesmer-Magnus et al. (2012) term "a culture of citizenship and ethicality" (Miller \& Lee, 2001; Subramony et al., 2008). HR investments contribute to more positive attitudes among employees in light of the norm of reciprocity premise. Authors such as Florea et al., (2013), Gollan (2005), Kramar (2014) and Zink (2014) recognize that sustainable HRM overlaps with a socially responsible human resources management in which the company's investments in improving its employees' wellbeing will be matched in the form of greater effort and motivation in their work place, generating a social climate of trust and collaboration between the organization and employees that is sustainable in the long term. Sustainable organizations act in the expectation of receiving the benefit of taking employee well-being into consideration (Kobayashi et al., 2018).

The social context within which the norm of reciprocity develops is too complex to be contained in only one of these two spheres, so the integration of society and business becomes more evident. The sustainability values of trust and cooperation inherent in the norm of 
reciprocity that shape the social climate among a group of people, both a society and an organization, allow a connection between the environment and business strategy, thus regulating the mutual influence between poverty and inequality, and HR investments. Athanasopoulou and Selsky (2015) explain that people are immersed simultaneously in two basic social contexts, namely, the organization in which they work and the society in which they live, and find it difficult to demarcate the two realities. For this reason, when a person develops an attitude of trust or a cooperative behavior in one of these two spheres, it inevitably transfers to the other. The respective social norms or ethical values developed in one of these two areas influences the other, tending in the long term to a significant correspondence. In other words, the values and behaviors of employees are shared by society and by the business.

Therefore, if employees are immersed in an impoverished and/or unequal socioeconomic environment, they transfer the values of lack of confidence and reduced cooperation to their own work, limiting their involvement with the organization and hindering a social climate of collaboration in the company. Obviously, this anti-cooperative behavior makes it difficult to implement the HR investment strategy, which promotes the development of ethical or positive values at the organizational level. In this sense, authors such as Bapuji (2015) and Leana and Meuris (2015) indicate that the community around an organization can influence the behavior of people within it and organizations might engage in less socially responsible behavior when they are located in a poor and/or unequal socioeconomic environment.

In the reverse direction, the impact of HR practices on the social dimension of the environment is one of the basic points of the sustainable HRM perspective (Ehnert et al., 2014; Mariappanadar, 2014). As Zink (2014) states, as people spend more time in their jobs, this is the most appropriate place to learn and apply sustainability. Why should people act sustainably as citizens if they have never had the opportunity to do so as employees? Only people who work in a company in a sustainable manner are able to prioritize and move towards the social 
sustainability of society (Pfeffer, 2010). The development of positive values and attitudes in people increasingly depends on how they are treated as relevant and valued human resources at work. The HR investment strategy allows this set of human capacities, created in the workplace, to be externalized to the society in which the organization operates, thus counteracting the noncooperative values generated by poverty and income inequality. Positive reciprocity between an organization and employees improves the organizational social climate and, ultimately, affects the welfare of society (Hutchins \& Sutherland, 2008).

In addition, sustainable HRM adopts the general systems theory (Kast \& Rosenzweig, 1972) and maintains that an organization is an open system in constant interaction with its environment, which receives its inputs from and returns its outputs to the environment (Athanasopoulou \& Selsky, 2015; Jabbour \& Santos, 2008, Kramar, 2014, Renwick et al., 2013). It is therefore a continuous flow of inputs and outputs that forms a feedback loop between the environment and the business that contributes to achieving a stable state of dynamic equilibrium between both spheres in the long term. This interactive process implies the recognition that society and business are interdependent (Ehnert et al., 2016, Kramar, 2014). If we apply this systemic approach to social sustainability, then ethical values and positive employee behaviors become the product (input/output) that flows between business and society. The features of society (i.e., poverty and inequality) and business (i.e., HR investment strategy) contribute to improve (or deteriorate) that product. While the HR investment strategy "produces" ethical values in organizations, poverty and income inequality "produce" unethical values in society. This input-output representation helps describe the social flow to/from business in response to changes in society (Hutchins \& Sutherland, 2008).

In this way, a positive feedback process is set up between the social sustainability of society and business, where the greater the implementation of the HR investment strategy in organizations, the lower the poverty and income inequality of society, and vice versa. This 
circular relationship between society and business means that sustainable HRM develops mutually beneficial relationships for both entities and that, in turn, they regenerate over time (Ehnert et al., 2016). Thus, there is a positive bidirectional relationship between the social sustainability of society and the social sustainability of the organizations located within that society. This positive interdependence is expressed in our study in a negative sense, given that we examine two characteristics that are contrary to a society's social sustainability - namely poverty and inequality_ in such a way that we propose the following two hypotheses:

H1. There is a negative two-way relationship between the poverty of society and businesses' HR investment strategy

H2. There is a negative two-way relationship between the inequality of society and businesses' HR investment strategy

\section{METHODOLOGY}

\subsection{Information sources and measures}

To test the above hypotheses, data from two basic public information sources in Spain were used: 1) the Survey on Business Strategies (Encuesta sobre Estrategias Empresariales, ESEE) prepared by the SEPI (Sociedad Estatal de Participaciones Industriales) Foundation, attached to the Ministry of Industry; and 2) the Living Conditions Survey (Encuesta de Condiciones de Vida, ECV), from which the National Institute of Statistics (Instituto Nacional de Estadística, INE) calculates the AROPE (At Risk of Poverty and/or Exclusion) index and the Gini coefficient for Spanish regions (i.e., autonomous communities). Spain is a quasifederal country with extensively decentralized basic public services (health, education and 
social protection) in its 17 autonomous communities, corresponding to NUTS 2 level regions in Europe (Eurostat, 2015) $)^{2}$.

The ESEE is an annual survey whose statistical population is the Spanish industrial firms with 10 or more workers. Firms are selected on the basis of a combination of exhaustiveness and random sampling criteria. by SEPI Foundation. The ESEE is a high-quality database representative of the Spanish context that provides information based on panel data, and sustains a wide empirical economic research carried out by both the internal services of the Ministry of Industry and a growing number of researchers who request such data from the SEPI Foundation (SEPI Foundation, 2018). The SEPI Foundation is responsible for the survey's design and administration, and all information contained in the ESEE is subjected to quality controls and logical consistence.

The ECV is an annual survey whose statistical population is Spanish households. In the $\mathrm{ECV}$, the incomes used to calculate the AROPE index and the Gini coefficient correspond to the previous year. Both indicators are used by the European Commission to measure, respectively, the degree of poverty and inequality of the regions in Europe (Piacentini, 2014). We use the ECV data for the 2011-2016 period. These six years were selected mainly because in Europe (Piacentini, 2014), and particularly in Spain (Llano, 2017), the diversity of the regions in terms of poverty and inequality is greater during this period than before the crisis. Figure 1 shows that there is no pattern of common evolution between Spanish regions. In addition, similarly to Cobb and Steven's (2017) analysis of the states in the USA, we chose the

\footnotetext{
${ }^{2}$ Eurostat identifies the cities of Ceuta and Melilla as NUTS 2 territories, extending the Spanish regions to 19. However, the INE does not calculate the Gini coefficient for these two territories given the limited sample of population. Likewise, neither does ESEE include these two territories in its scope of study. Our study is therefore limited to analyzing organizations in the 17 autonomous communities.
} 
autonomous communities in Spain because the annual historical data of poverty and inequality for other subnational entities (e.g., provinces) are not available in the ECV.

Figure 1. Evolution of income inequality and poverty by autonomous communities

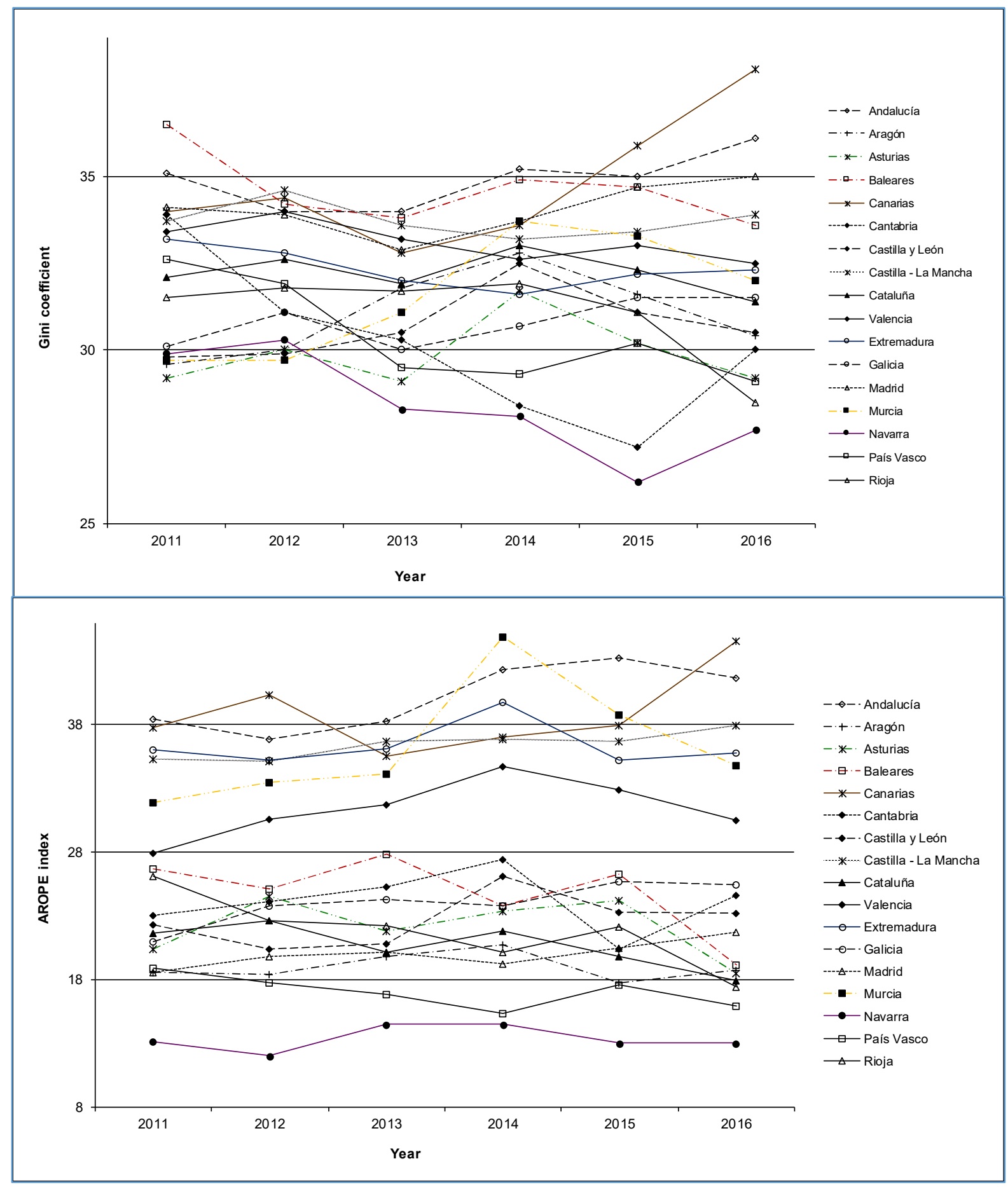

Source: INE 
We combine the annual data from the ECV and the ESEE in such a way that the unit of analysis is the company. This fusion requires identifying the region in which a firm performs its productive activity in order to assign it the corresponding AROPE and Gini indices for each of the six years analyzed. To do this, we only selected those companies located in a single autonomous community and that did not change their location during the period of time analyzed. Moreover, there is a time lag of one year between the ECV and the ESEE databases that must be adjusted. As noted above, income in the ECV data always corresponds to the previous year, while this is not the case for the ESEE, in which the annual data collected actually correspond to the year indicated. Therefore, for the data to be temporally consistent, we use the ESEE data corresponding to the 2010-2015 period and the ECV data for the years 2011-2016.

From the original ESEE sample for 2010-2015 period, we remove firms with industrial premises located in more than one region and those that moved from one region to another during the period studied (184 firms). Additionally, as the SEPI Foundation (2018) warns, we eliminated firms affected by takeovers, divisions or mergers (206 firms), all of which prevent data being compared over time. The final sample (N) contained 2,052 firms; their distribution by region can be seen in Table 1. Usually, the cases eliminated in this debugging process correspond to large companies, so the average organizational size of the original sample (185.38 employees) during the six-year period is reduced in the final sample to 112.80 employees.

Table 1. Distribution of the number of firms by autonomous communities

\begin{tabular}{|l|c|c|}
\hline Andalucía & 197 & $9.6 \%$ \\
\hline Aragón & 69 & $3.4 \%$ \\
\hline Asturias, Principado de & 50 & $2.4 \%$ \\
\hline Balears, Illes & 27 & $1.3 \%$ \\
\hline Canarias & 29 & $1.4 \%$ \\
\hline Cantabria & 25 & $1.2 \%$ \\
\hline Castilla y León & 117 & $5.7 \%$ \\
\hline Castilla - La Mancha & 108 & $5.3 \%$ \\
\hline Cataluña & 450 & $21.9 \%$ \\
\hline
\end{tabular}




\begin{tabular}{|l|c|c|}
\hline Comunitat Valenciana & 290 & $14.1 \%$ \\
\hline Extremadura & 35 & $1.7 \%$ \\
\hline Galicia & 135 & $6.6 \%$ \\
\hline Madrid, Comunidad de & 209 & $10.2 \%$ \\
\hline Murcia, Región de & 65 & $3.2 \%$ \\
\hline Navarra, Comunidad Foral de & 69 & $3.4 \%$ \\
\hline País Vasco & 145 & $7.1 \%$ \\
\hline Rioja, La Total & 32 & $1.6 \%$ \\
\hline \multicolumn{2}{|c|}{$\quad \mathbf{2 , 0 5 2}$} & $\mathbf{1 0 0 \%}$ \\
\hline
\end{tabular}

With regard to the organizational variables, we use the measure devised by Roca-Puig et al. (2012, 2018), extracted from the ESEE, which comprises three of the HR practices (i.e., compensation level, training, and permanent work contracts) commonly used in previous studies to measure an investment HR strategy (e.g., Batt \& Colvin, 2011; Roh \& Kim, 2016; Subramony et al., 2008), and which are a manifestation of organizational commitment to employees (Miller \& Lee, 2001). An investment HR strategy is calculated as the arithmetic mean of the standardized values of employee compensation, training expenses and permanent contracts. The remuneration is calculated as the ratio between the labor cost and the total number of employees. In Spain, labor costs include wages and salaries, compensation fees, national insurance contributions, pension scheme payments and other social expenditures. The investment in training is calculated as the ratio between the training expense and the total number of employees of the company. The proportion of permanent contracts is calculated as the percentage of employees with a fixed contract with respect to the total number of employees in the company. In Spain, temporary work contracts are characterized by higher job insecurity and poorer working conditions than those of permanent work contracts. Finally, we introduce the organizational size and the capital intensity of the company as control variables that can affect the investment HR strategy. Following Huselid (1995), the organizational size is measured by the logarithm of the total number of employees of the company, and the capital 
intensity is calculated as the logarithm of the ratio between the net fixed assets and the total number of employees.

\subsection{Statistical procedure}

Following the indications of Little (2013), we estimate a cross-lagged panel model using longitudinal structural equation modeling. Figure 1 shows the autoregressive effects (causal relationships between the same variable over time) and the cross-effects (causal relationships between different variables over time) typical of this kind of longitudinal model. We propose a time lag of one year in these cross-lagged effects and, to ensure greater parsimony of the model, the magnitude of all these effects was constrained to be equal over time. In longitudinal analysis, researchers often specify such constraints to facilitate interpretation of the results (Cole \& Maxwell, 2003). We estimate one model for poverty and another similar model for inequality, since the complexity in the design of longitudinal analysis suggests their separate study. In addition, for various reasons, each year some firms disappear from the ESEE database and new firms are included, so during the six-year period analyzed there are incomplete cases. This situation is typical of longitudinal analysis, and as a result, the full-information maximum likelihood (FIML) procedure is recommended for estimating the parameters of the model, in order to take advantage of all the available information and to avoid bias in the estimated parameters that the elimination of incomplete cases (i.e., listwise deletion) could imply (Little, 2013). The two cross-lagged panel models (poverty and inequality) were estimated using FIML with EQS software (Bentler, 2006). In addition, robust standard errors were used to protect inferences from non-normality of the data (Shin et al., 2009). To assess fit of the model to the data, for each model we report the Yuan-Bentler scaled chi-square statistic $\left(\chi^{2}\right)$, the BentlerBonett non-normed fit index (BBNFI), the comparative fit index (CFI), the root mean square error of approximation (RMSEA), and the standardized root mean square residual (SRMR). 
Figure 1. Longitudinal structural equation model $(t=6)$

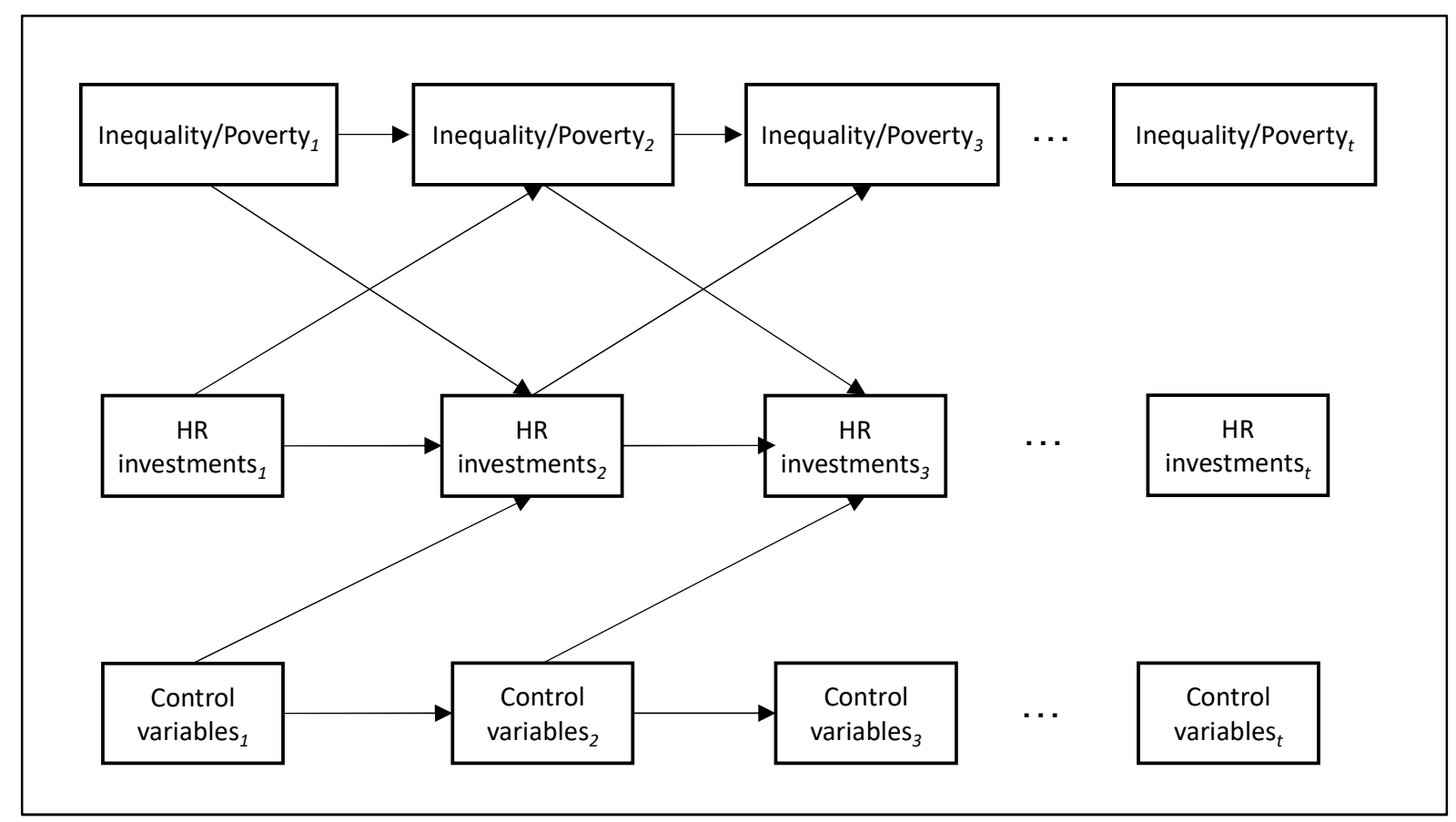

\section{RESULTS}

With missing data, the FIML method computes the "imputed estimates of means and sample covariance matrix based on the structured model" and this can be used like matrix input to get the final structural model parameter estimates (Bentler, 2006). The appendix (Tables I and II) shows these two matrices of data used to analyze inequality and poverty models. Table 1 shows the non-standardized estimated parameters of the inequality and poverty models. Both models present an acceptable fit to the data, as attested by the goodness-of-fit indices (Income inequality: scaled $\chi_{(216)}=2,345.731 p=0.000 ; \mathrm{BBNFI}=0.939 ; \mathrm{CFI}=0.952 ; \mathrm{RMSEA}=0.069$; SRMR $=0.038 ; \quad$ Poverty: $\quad$ scaled $\quad \chi_{(216)}=1,886.187 \quad p=0.000 ; \quad$ BBNFI $=0.958 ; \quad$ CFI $=0.967$; RMSEA $=0.061 ; \mathrm{SRMR}=0.028)$. As we can see, hypothesis 1 is confirmed since a negative twoway causal relationship between poverty and the HR investment strategy is manifested over time Poverty $_{t} \rightarrow$ HR investment strategy ${ }_{t+1}:-0,005 ;$ HR investment strategy $y_{t} \rightarrow$ Poverty $_{t+1}:-$ 0,185). In contrast, results do not support hypothesis 2. Although it is evident that HR 
investment strategy has a negative and significant impact on inequality during the analyzed period (HR investment strategy $\rightarrow$ Income inequality $t_{t+1}:-0,068$ ), the reverse negative effect is not significant (Income inequality $\rightarrow$ HR investment strategy $\left.y_{t+1}:-0,002\right)$. Therefore, only one unidirectional causal relationship appears between these two variables.

Table 1. Results of longitudinal models ${ }^{1}$

\begin{tabular}{|c|c|}
\hline Causal relationships & Parameter estimates \\
\hline HR investment strategy ${ }_{t} \rightarrow$ Income inequality ${ }_{t+1}$ & $-0.068 * * *$ \\
\hline Income inequality $t \rightarrow$ HR investment strategy $t_{t+1}$ & -0.002 \\
\hline Organizational size $t_{t} \rightarrow$ HR investment strategy $t+1$ & $0.068 * * *$ \\
\hline Capital intensity $t \rightarrow$ HR investment strategy $t_{t+1}$ & $0.025^{* * *}$ \\
\hline Income inequality $t \rightarrow$ Income inequality $t_{t+1}$ & $(0.783-1.065)^{* * *}$ \\
\hline HR investment strategy $t \rightarrow$ HR investment strategy $t_{t+1}$ & $(0.639-0.887)^{* * *}$ \\
\hline Organizational size $t_{t} \rightarrow$ Organizational size $_{t+1}$ & $(1.002-1.012)^{* * *}$ \\
\hline Capital intensity $_{t} \rightarrow$ Capital intensity $_{t+1}$ & $(0.934-0.980)^{* * *}$ \\
\hline HR investment strategy ${ }_{t} \rightarrow$ Poverty $_{t+1}$ & $-0.185^{* * *}$ \\
\hline Poverty $t_{t} \rightarrow$ HR investment strategy ${ }_{t+1}$ & $-0.005^{* * *}$ \\
\hline Organizational size $t_{t} \rightarrow$ HR investment strategy $t_{t+1}$ & $0.066^{* * *}$ \\
\hline Capital intensity $_{t} \rightarrow$ HR investment strategy $_{t+1}$ & $0.035^{* * *}$ \\
\hline Poverty $_{t} \rightarrow$ Poverty $_{t+1}$ & $(0.933-1.164)^{* * *}$ \\
\hline HR investment strategy $y_{t} \rightarrow$ HR investment strategy $y_{t+1}$ & $(0.623-0.873)^{* * *}$ \\
\hline Organizational size $t_{t} \rightarrow$ Organizational size $t_{t+1}$ & $(1.002-1.011)^{* * *}$ \\
\hline Capital intensity $t_{t} \rightarrow$ Capital intensity $_{t+1}$ & $(0.933-0.980)^{* * *}$ \\
\hline
\end{tabular}

\footnotetext{
${ }^{1}$ Note. Autoregression coefficients are not equal over time and therefore the range of variation (minimum maximum) reached during the six-year period is shown in parenthesis. $N=2,052 .{ }^{*} p<0.10 ; * * p<0.05 ; * * * p$ $<0.01$
}

\section{DISCUSSION AND CONCLUSIONS}

Hutchins and Sutherland (2008) posit that indicators on the economic resources available to a family (i.e., poverty and inequality) may be linked to firm actions (i.e., HR 
investment strategy). The sustainable HRM approach emphasizes and develops this idea by defending a mutual influence between these two dimensions of social sustainability. From this theoretical approach, we empirically analyzed the presence of a negative bidirectional relationship between them over time. Our results partially support this proposition. We reveal that poverty and HR investment strategy influence each other, such that one of them is the cause and effect of the other at different moments of time, establishing a circular relationship. In contrast, the HR investment strategy is identified as a cause of income inequality, but income inequality is not confirmed as an explanatory factor of the HR investment strategy. These results validate the important role of companies, particularly their human resources management strategy, in achieving a sustainable development of society, given that the HR investment strategy reduces both poverty and inequality in society. Therefore, as Cobb (2016) and Pfeffer (2010) postulate, in addition to the macroeconomic characteristics (e.g., technological progress, globalization) that have usually been identified as causing the sustainable development of society, human resource management emerges as another significant explanatory factor at the microeconomic level. Individual corporate decisions on social sustainability can affect social sustainability of society (Hutchins \& Sutherland, 2008).

\subsection{Theoretical and practical implications}

Authors such as Mesmer-Magnus et al., (2012), Rogers et al., (2012) and Athanasopoulou and Selsky (2015) claim that social sustainability is immersed in different areas of analysis (i.e., society and business), and are inherently associated. We recognize the norm of reciprocity, which regulates socio-economic exchanges and collaborative behavior among members of a group, as a basic value of social sustainability that acts as an underlying driver of social sustainability which can bridge the gap between organizational sustainability and environmental sustainability and explain a societal/business circular relationship (Florea et al., 2013; Mesmer-Magnus et al. 2012). Any variation in the degree of implementation of this 
social principle in either of these two areas will produce a significant variation in the same direction in the other.

This circular relationship draws a positive feedback loop that reinforces itself over time, where inputs produce more outputs, which in turn produce more inputs. The presence of a feedback loop constitutes a distinctive feature of the general system theory, adopted by the sustainable HRM literature (e.g., Kramar, 2014). Organizational social sustainability and societal social sustainability are mutually reinforcing (weakening) through this dynamic process. An improvement (decline) of the societal social sustainability at a moment of time $(t)$ will produce an increase (reduction) in the organizational social sustainability in the future $(t+1)$, which in turn will subsequently $(t+2)$ cause an improvement (decline) in societal social sustainability. A similar feedback loop will occur if the organizational social sustainability is improved (declined) in a moment of time $(t)$. Therefore, this "spiral of social sustainability" can lead to a virtuous (vicious) circle that is not easily modified because it is consolidated over time. Recently, poverty and inequality have increased considerably in most developed countries (Cobb, 2016, Piacentini, 2014), particularly in Spain (Llano, 2017). We may therefore be witnessing the birth of a vicious circle between society (i.e., poverty) and business (i.e., HR investment strategy) in the Spanish context. It will take a powerful external force to alter the direction of this interactive process.

Public institutions, especially regional governments, could be this external agent, given that they have sufficient capacity to significantly influence social sustainability. In the societal sphere, they can encourage social assistance to reduce poverty and inequality. In the field of the business, they can promote the HR investment strategy in firms, through reforms in labor legislation or the creation of tax reductions and advantages when public administrations contract firms that implement and improve this HR strategy. As Sharma and Ruud (2003) argue, promoting sustainable development requires governments to incorporate the social principles 
of equity, justice and cooperation into the design of public policies that encourage companies to develop more sustainable strategies.

Likewise, organizations must assume their social responsibility in the form of greater investment in employees, since if the company does not accept this role it will harm society, which in turn will incur a social cost in terms of less equity and social inclusion (Pfeffer, 2010). Our results provide empirical evidence to corroborate this statement. Moreover, due to the feedback loop between poverty and HR investment strategy, employers should be aware that this social cost, initially borne by the society, will have a negative impact on the companies themselves in the long term, causing a "boomerang effect" in the form of less reciprocity and lack of trust among citizens, who will bring these negative attitudes and values to their own job, thus hindering the creation of a social climate of collaboration and cooperation in the company that, according to authors such as Subramony (2008), Miller and Lee (2001), and MesmerMagnus et al. (2012), is the source of a sustainable competitive advantage for companies. According to the 2030 Agenda for Sustainable Development, public institutions and private companies are all responsible for promoting social sustainability in their respective fields of action, given that their interdependence makes it necessary to work together towards the common goal of improving individuals' well-being (Rogers et al., 2012).

Algo de HR practices y sociedad Cobb ....

Today the impact of business on environmental issues are more apparent and companies have to effectively address moral and social obligations to protect both their interests and the environment, and as demonstrated in our research, HR practices have a key role to achieve it (Siyambalapitiya et al. ., 2018). Furthermore, social sustainability dimension have a significant task to play in the uptake of cleaner production. As Stone states (2000), cleaner production is not only about changing raw materials, processes and products, but it is also 
about changing the corporate culture and the attitudes of people. In this sense, authors such as Jabbour et al, (2015), Jabbbour and de Sousa Jabbour (2016), and Missimer et al., (2017a,b), underline that human resources management practices and social aspects are critical in creating a sustainable organizational culture, based on trust and cooperative values, which can facilitate the adoption of more advanced environmental practices, such as green supply chain (Awan et al., 2018), sustainable product development (Gould et al., 2017), and the implementation of an environmental management systems (Jabbour et al, 2015).

\subsection{Limitations and future research}

As we have indicated previously, the concept, indicators, and tools used to measure social sustainability still lack clarity and maturity (Ajmal et al., 2017; Staniškienè \& Stankevičiūtè, 2018). We followed Hutchins and Sutherland's (2008) approach to operationalize organizational social sustainability through a few representative and quantifiable indicators available from consistent and public corporate databases (i.e., ESEE). In our case, these indicators focus on operationalizing an investment HR strategy, which promotes trust, employee cooperation and, ultimately, employee well-being. They represent a starting point to empirically examine the path of social sustainability between business and society over time. Longitudinal studies are complex and scarce in sustainability HRM literature, so our methodology can be useful for future research. Thus, one could deepen the proposed model by comparing between different regions depending on their degree of industrialization or competitiveness to examine whether the circular social path works equally or, on the contrary, differences appear. Given the small number of regions in Spain, this segmentation is not possible since the variability of the variables poverty and income inequality would be greatly reduced and statistical problems appear, and it is therefore required to increase the number of 
regions (for example, by expanding the geographical area to Europe and introducing regions of different countries).

While much research has focused on sustainability to examine the ecological impact of business activity (e.g., consumption of natural resources and energy) or to analyze the impact of sustainability practices on a company's balance sheet, few studies have reflected on what sustainability means when dealing with people. The relevance of human resource management in developing a sustainable organization has often been marginalized. However, taking sustainability seriously as a business strategy soon or later leads us to human resources management (Ehnert et al., 2014). In order to compensate this imbalance, we focused our research on the social dimension rather than ecological and economic facets of sustainability. Future research could incorporate these dimensions to form a comprehensive organizational sustainability framework (Peterson, 2016). For example, Liu et al., (2018) confirm the link between income inequality and environmental degradation, therefore if we introduce this variable in our model, we could examine the indirect relationship, via income inequality, between HR investment and environmental pollution. Likewise, Rao et al., (2017) defend the influence of climate change and climate policies on poverty and income inequality of societies, so by applying our model we could examine the indirect effect on companies of these environmental variables. The opportunities and challenges that climate presents to organizations and how they respond to it has recently been studied by Seles et al., (2018). In short, applying our model we can invert the order of traditional priority in the sustainability literature, putting social sustainability at the center of the enquiry.

\section{Acknowledgments:}

This work was supported by the Spanish Ministry of Science and Innovation (Ref. ECO201566671-P (MINECO/FEDER)). 


\section{REFERENCES}

Ajmal, M. M., Khan, M., Hussain, M., \& Helo, P. (2018). Conceptualizing and incorporating social sustainability in the business world. International Journal of Sustainable Development \& World Ecology, 25(4), 327-339.

Athanasopoulou, A., \& Selsky, J. (2015). The social context of corporate social responsibility: Enriching research with multiple perspectives and levels. Business \& Society, 54, 322364. https://doi.org/10.1177/0007650312449260

Awan, U., Kraslawski, A., \& Huiskonen, J. (2018). Buyer-supplier relationship on social sustainability: Moderation analysis of cultural intelligence. Cogent Business \& Management, 5(1), 1429346.

Ayala, L. y Jurado, A. (2015). "Pro-poor economic growth, inequality and fiscal policy: The case of spanish regions". Regional Studies, 45, 103-121.

Bapuji, H. (2015). Individuals, interactions and institutions: How economic inequality affects organizations. Human $\quad$ Relations, $\quad$ 68(7), https://doi.org/10.1177/0018726715584804

Batt, R., \& Colvin, A.J. (2011). An employment systems approach to turnover: Human resources practices, quits, dismissals, and performance. Academy of Management Journal, 54(4), 695-717. https://doi.org/10.5465/amj.2011.64869448

Bentler, P.M. (2006). EQS 6 Structural Equation Program Manual. Encino, CA: Multivariate software, Inc.

Boström, M. (2012). A missing pillar? Challenges in theorizing and practicing social sustainability: introduction to the special issue. Sustainability: Science, practice and policy, 8(1), 3-14.

Bourguignon, F. (2004). The poverty-growth-inequality triangle. Agence Française de Développement, Paris. 
Broman, G. I., \& Robèrt, K. H. (2017). A framework for strategic sustainable development. Journal of Cleaner Production, 140, 17-31.

Čiegis, R., Gavenauskas, A., Petkevičiūte, N., \& Štreimikiene, D. (2008). Ethical values and sustainable development: Lithuanian experience in the context of globalisation. Technological and Economic Development of Economy, 14(1), 29-37.

Cobb, J.A. (2016). How firms shape income inequality: Stakeholder power, executive decision making, and the structuring of employment relationships. Academy of Management Review, 41, 324-348. https://doi.org/10.5465/amr.2013.0451

Cobb, J.A., \& Stevens, F.G. (2017). These unequal states: Corporate organization and income inequality in the United States. Administrative Science Quarterly, 62, 304-340. https://doi.org/10.1177/0001839216673823

Cole, D.A., \& Maxwell, S.E. (2003). Testing mediational models with longitudinal data: Questions and tips in the use of structural equation modeling. Journal of Abnormal Psychology, 112, 558-577. https://doi.org/10.1037/0021-843X.112.4.558

Cropanzano, R., and Mitchell, M.S. (2005). Social exchange theory: An interdisciplinary review. Journal of Management, 31(6), 874-900.

Ehnert I., Harry W. \& Zink K.J. (2014) Sustainability and HRM. In: Ehnert I., Harry W. and Zink K.J. (eds.) Sustainability and Human Resource Management. CSR, Sustainability, Ethics \& Governance. Springer, Berlin Heidelberg, 3-32.

Ehnert, I., Parsa, S., Roper, I., Wagner, M., \& Muller-Camen, M. (2016). Reporting on sustainability and HRM: A comparative study of sustainability reporting practices by the world's largest companies. International Journal of Human Resource Management, 27, 88-108. https://doi.org/10.1080/09585192.2015.1024157

Eurostat (2015). Regions in the European Union. Nomenclature of territorial units for statistics NUTS, 2013/EU-28. European Union. 
Florea, L., Cheung, Y.H., \& Herndon, N.C. (2013). For all good reasons: Role of values in organizational sustainability. Journal of Business Ethics, 114, 393-408. https://doi.org/10.1007/s10551-012-1355-x

Gollan, P.J. (2005). High involvement management and human resource sustainability: The challenges and opportunities. Asia Pacific Journal of Human Resources, 43, 18-33. https://doi.org/10.1177/1038411105050305

Gould, R., Missimer, M., \& Mesquita, P. L. (2017). Using social sustainability principles to analyse activities of the extraction lifecycle phase: Learnings from designing support for concept selection. Journal of cleaner production, 140, 267-276.

Gouldner, A. (1960). The norm of reciprocity: A preliminary statement. American Sociological Review, 25, 161-178. https://doi.org/10.2307/2092623

Haushofer, J., and Fehr, E. (2014). On the psychology of poverty. Science, 344(6186), 862-867. $10.1126 /$ science. 1232491

Hughes, C.P., Semeijn, J., \& Caniëls, M. (2017). The sustainability skew. Current opinion in environmental sustainability, 28, 58-63. https://doi.org/10.1016/j.cosust.2017.08.004

Huselid, M.A. (1995). The impact of human resource management practices on turnover, productivity, and corporate financial performance. Academy of Management Journal, 38, 635-672. https://doi.org/10.2307/256741

Hutchins, M.J., \& Sutherland, J.W. (2008). An exploration of measures of social sustainability and their application to supply chain decisions. Journal of Cleaner Production, 16, 1688-1698 https://doi.org/10.1016/j.jclepro.2008.06.001

Jabbour, C. J. C., \& de Sousa Jabbour, A. B. L. (2016). Green human resource management and green supply chain management: Linking two emerging agendas. Journal of Cleaner Production, 112, 1824-1833. 
Jabbour, C. J. C., Jugend, D., de Sousa Jabbour, A. B. L., Gunasekaran, A., \& Latan, H. (2015). Green product development and performance of Brazilian firms: measuring the role of human and technical aspects. Journal of Cleaner Production, 87, 442-451.

Jabbour, C.J., \& Santos, F.C. (2008). The central role of human resource management in the search for sustainable organizations. International Journal of Human Resource Management, 19, 2133-2154.https://doi.org/10.1080/09585190802479389

Jiang, L., \& Probst, T. M. (2017). The rich get richer and the poor get poorer: Country-and state-level income inequality moderates the job insecurity-burnout relationship. Journal of Applied Psychology, 102, 672. https://doi.org/10.1037/ap10000179

Kast, F.E., \& Rosenzweig, J.E. (1972). General systems theory: Applications for organization and management. Academy of Management Journal, 15, 447-465. https://doi.org/10.5465/255141

Kis, A. B. y Gábos, A. (2015). “Consistent poverty across the EU”. ImPRovE working Paper No.15/22, University of Antwerp.

Kobayashi, K., Eweje, G., \& Tappin, D. (2018). Employee wellbeing and human sustainability: Perspectives of managers in large Japanese corporations. Business Strategy and the Environment. https://doi.org/10.1002/bse.2032

Kramar, R. (2014). Beyond strategic human resource management: Is sustainable human resource management the next approach? International Journal of Human Resource Management, 25, 1069-1089.https://doi.org/10.1080/09585192.2013.816863

Leana, C.R., \& Meuris, J. (2015). Living to work and working to live: Income as a driver of organizational behavior. Academy of Management Annals, 9, 55-95. https://doi.org/10.1080/19416520.2015.1007654

Little, T.D. (2013). Longitudinal structural equation modeling. Guilford Press, New York. 
Liu, Q., Wang, S., Zhang, W., \& Li, J. (2018). Income distribution and environmental quality in China: A spatial econometric perspective. Journal of Cleaner Production, 205, 1426.

Llano, J.C. (2017). El estado de la pobreza. Seguimiento del indicador de riesgo de pobreza y exclusión social en España. EAPN (European Anti-Poverty Network) España, Madrid.

Macke, J., \& Genari, D. (2019). Systematic Literature Review on Sustainable Human Resource Management. Journal of Cleaner Production., 208, 806-815.

Mariappanadar, S. (2014). The model of negative externality for sustainable HRM. In: Ehnert I., Harry W. and Zink K.J. (eds.) Sustainability and Human Resource Management. CSR, Sustainability, Ethics \& Governance. Springer, Berlin Heidelberg, 181-203.

Mesmer-Magnus, J., Viswesvaran, C., \& Wiernik, B. M. (2012). The role of commitment in bridging the gap between organizational sustainability and environmental sustainability. In Jackson, S.E., Ones, D.S., and Dilchert, S. (eds.), Managing human resources for environmental sustainability. Jossey-Bass/Wiley, San Francisco, 155-186.

Miller, D., \& Lee, J. (2001). The people make the process: commitment to employees, decision making, and performance. Journal of Management, 27, 163-189. https://doi.org/10.1177/014920630102700203

Missimer, M., Robèrt, K. H., \& Broman, G. (2017a). A strategic approach to social sustainability-Part 1: exploring the social system. Journal of Cleaner Production, 140, $32-41$.

Missimer, M., Robèrt, K. H., \& Broman, G. (2017b). A strategic approach to social sustainability-Part 2: a principle-based definition. Journal of cleaner production, 140, 42-52. 
Peterson, N. (2016). Introduction to the special issue on social sustainability: integration, context, and governance. Sustainability: Science, Practice and Policy, 12(1), 3-7. https://doi.org/10.1080/15487733.2016.11908148

Pfeffer, J. (2010). Building sustainable organizations: The human factor. Academy of Management Perspectives, 24, 34-45. https://doi.org/10.5465/amp.24.1.34

Piacentini, M. (2014). Measuring income inequality and poverty at the regional level in OECD countries, Statistics Working Papers, 2014/03, OECD (Organisation for Economic Cooperation and development) Publishing, Paris.

Pitesa, M., Thau, S., \& Pillutla, M. (2017). Workplace trust as a mechanism of employee (dis) advantage: The case of employee socioeconomic status. Research in Organizational Behavior, 37, 83-101. https://doi.org/10.1016/j.riob.2017.10.006

Rao, N. D., van Ruijven, B. J., Riahi, K., \& Bosetti, V. (2017). Improving poverty and inequality modelling in climate research. Nature Climate Change, 7(12), 857.

Renwick, D.W., Redman, T., \& Maguire, S. (2013). Green human resource management: A review and research agenda. International Journal of Management Reviews, 15, 1-14. https://doi.org/10.1111/j.1468-2370.2011.00328.x

Roca-Puig, V., Beltrán-Martín, I., \& Segarra-Ciprés, M. (2012). Commitment to employees, labor intensity, and labor productivity in small firms: a non-linear approach. International Journal of Manpower, 33, 938-954. https://doi.org/10.1108/01437721211280399

Roca-Puig, V., Bou-Llusar, J. C., Beltrán-Martín, I., and García-Juan, B. (2018) The virtuous circle of human resource investments: A precrisis and postcrisis analysis. Human Resource Management Journal. https://doi.org/10.1111/1748-8583.12213

Rogers, D.S., Duraiappah, A.K., Antons, D.C., Munoz, P., Bai, X., Fragkias, M., \& Gutscher, H. (2012). A vision for human well-being: transition to social sustainability. Current 
Opinion in Environmental Sustainability, 4(1), 61-73. https://doi.org/10.1016/j.cosust.2012.01.013

Roh, H., \& Kim, E. (2016). The business case for gender diversity: examining the role of human resource management investments. Human Resource Management, 55(3), 519-534. https://doi.org/10.1002/hrm.21736

Seles, B. M. R. P., de Sousa Jabbour, A. B. L., Jabbour, C. J. C., de Camargo Fiorini, P., MohdYusoff, Y., \& Thomé, A. M. T. (2018). Business opportunities and challenges as the two sides of the climate change: Corporate responses and potential implications for big data management towards a low carbon society. Journal of Cleaner Production, 189, 763-774.

SEPI Foundation (2018). "Survey on business strategy (ESEE)". Retrieved from https://www.fundacionsepi.es/investigacion/esee/en/spresentacion.asp. (Accessed 10 November 2018).

Sharma, S., \& Ruud, A. (2003). On the path to sustainability: Integrating social dimensions into the research and practice of environmental management. Business Strategy and the Environment, 12, 205-214. https://doi.org/10.1002/bse.366

Shin, T., Davison, M.L., \& Long, J.D. (2009). Effects of missing data methods in structural equation modeling with nonnormal longitudinal data. Structural Equation Modeling, 16(1), 70-98. https://doi.org/10.1080/10705510802569918

Siyambalapitiya, J., Zhang, X., \& Liu, X. (2018). Green Human Resource Management: A Proposed Model in the Context of Sri Lanka's Tourism Industry. Journal of Cleaner Production, 201, 542-555.

Staniškienè, E., \& Stankevičiūtè, Ž. (2018). Social sustainability measurement framework: The case of employee perspective in a CSR-committed organisation. Journal of Cleaner Production, 188, 708-719. https://doi.org/10.1016/j.jclepro.2018.03.269 
Stone, L. (2000). When case studies are not enough: the influence of corporate culture and employee attitudes on the success of cleaner production initiatives. Journal of Cleaner Production, 8(5), 353-359.

Subramony, M., Krause, N., Norton, J., \& Burns, G.N. (2008). The relationship between human resource investments and organizational performance: a firm-level examination of equilibrium theory. Journal of Applied Psychology, 93(4), 778-788. https://doi.org/10.1037/0021-9010.93.4.778

Wilkinson, R.G., \& Pickett, K.E. (2010). The spirit level: Why equality is better for everyone. Penguin UK.

Wilkinson, R.G., \& Pickett, K.E. (2017). The enemy between us: The psychological and social costs of inequality. European Journal of Social Psychology, 47, 11-24. https://doi.org/10.1002/ejsp.2275

Zink K.J. (2014). Social sustainability and quality of working life. In: Ehnert I., Harry W. and Zink K.J. (eds.) Sustainability and Human Resource Management. CSR, Sustainability, Ethics \& Governance. Springer, Berlin Heidelberg, 35-55.

Hollander, R., Amekudzi-Kennedy, A., Bell, S., Benya, F., Davidson, C., Farkos, C., Fasenfest, D., Guyer, R., Hjarding, A., Lizotte, M., Quigley, D., Watts, D., \& Whitefoot, K. (2016). Network priorities for social sustainability research and education: Memorandum of the Integrated Network on Social Sustainability Research Group. Sustainability: Science, Practice and Policy, 12(1), 16-21. https://doi.org/10.1080/15487733.2016.11908150 



\section{APPENDIX}

\section{Table I. Matrix input to poverty model.}

ARO1 ARO2 ARO3 ARO4 ARO5 ARO6 HRI1 HRI2 HRI3 HRI4 HRI5 HRI6 CAP1 CAP2 CAP3 CAP4 CAP5 CAP6 SIZ1 SIZ2 SIZ3 SIZ4 SIZ5 SIZ6 ARO1 47.445

ARO2 45.69546 .861

ARO3 $49.124 \quad 49.61155 .232$

ARO4 57.89158 .53564 .54580 .658

ARO5 $57.067 \quad 57.24363 .41475 .60275 .287$

ARO6 $56.650 \quad 56.548 \quad 63.07174 .15574 .01279 .987$

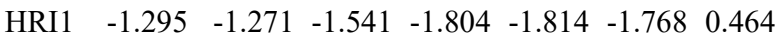

$\begin{array}{llllllllll}\text { HRI2 } & -1.296 & -1.261 & -1.513 & -1.769 & -1.781 & -1.741 & 0.368 & 0.434\end{array}$

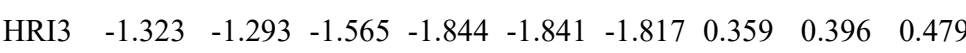

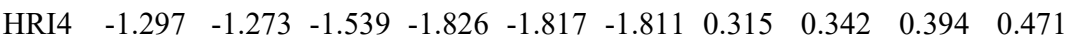

$\begin{array}{llllllllllll}\text { HRI5 } & -1.289 & -1.261 & -1.536 & -1.814 & -1.825 & -1.816 & 0.262 & 0.279 & 0.316 & 0.363 & 0.456\end{array}$

$\begin{array}{lllllllllllllll}\text { HRI6 } & -1.124 & -1.116 & -1.350 & -1.594 & -1.584 & -1.590 & 0.230 & 0.235 & 0.262 & 0.287 & 0.303 & 0.443\end{array}$

$\begin{array}{lllllllllllllll}\text { CAP1 } & 0.078 & 0.041 & -0.025 & 0.065 & 0.013 & 0.061 & 0.111 & 0.096 & 0.111 & 0.106 & 0.091 & 0.083 & 0.375\end{array}$

$\begin{array}{lllllllllllllllll}\text { CAP2 } & 0.126 & 0.092 & 0.023 & 0.122 & 0.700 & 0.119 & 0.114 & 0.108 & 0.123 & 0.116 & 0.100 & 0.088 & 0.364 & 0.408\end{array}$

$\begin{array}{lllllllllllllllll}\text { CAP3 } & 0.153 & 0.119 & 0.051 & 0.165 & 0.099 & 0.154 & 0.111 & 0.106 & 0.127 & 0.119 & 0.101 & 0.091 & 0.362 & 0.400 & 0.437\end{array}$

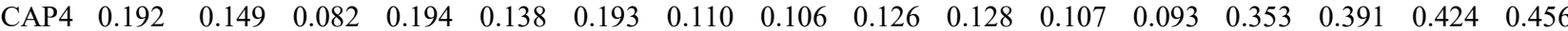

$\begin{array}{llllllllllllllllllllll}\text { CAP5 } & 0.207 & 0.163 & 0.095 & 0.211 & 0.141 & 0.190 & 0.112 & 0.106 & 0.127 & 0.125 & 0.107 & 0.096 & 0.341 & 0.376 & 0.405 & 0.427 & 0.461\end{array}$

$\begin{array}{llllllllllllllllllllll}\text { CAP6 } & 0.228 & 0.184 & 0.124 & 0.238 & 0.171 & 0.221 & 0.108 & 0.104 & 0.123 & 0.121 & 0.103 & 0.096 & 0.327 & 0.360 & 0.388 & 0.406 & 0.430 & 0.452\end{array}$

$\begin{array}{lllllllllllllllllllllll}\text { SIZ1 } & -0.411 & -0.392 & -0.455 & -0.474 & -0.540 & -0.514 & 0.106 & 0.103 & 0.118 & 0.114 & 0.097 & 0.095 & 0.106 & 0.111 & 0.114 & 0.114 & 0.112 & 0.109 & 0.263\end{array}$

$\begin{array}{llllllllllllllllllllllll}\text { SIZ2 } & -0.416 & -0.402 & -0.466 & -0.482 & -0.549 & -0.528 & 0.108 & 0.097 & 0.113 & 0.111 & 0.095 & 0.094 & 0.108 & 0.108 & 0.111 & 0.111 & 0.110 & 0.108 & 0.264 & 0.272\end{array}$

$\begin{array}{llllllllllllllllllllllllll}\text { SIZ3 } & -0.440 & -0.425 & -0.495 & -0.514 & -0.582 & -0.567 & 0.110 & 0.099 & 0.110 & 0.109 & 0.095 & 0.095 & 0.109 & 0.108 & 0.108 & 0.109 & 0.108 & 0.106 & 0.266 & 0.274 & 0.282\end{array}$

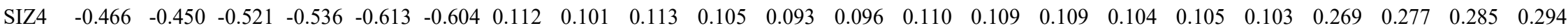

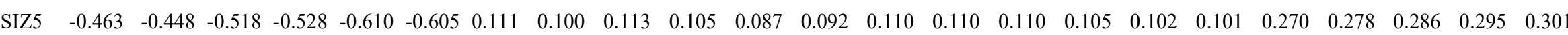

$\begin{array}{llllllllllllllllllllllllll}\text { SIZ6 } & -0.460 & -0.443 & -0.513 & -0.519 & -0.603 & -0.600 & 0.111 & 0.100 & 0.113 & 0.105 & 0.087 & 0.088 & 0.111 & 0.110 & 0.110 & 0.105 & 0.103 & 0.100 & 0.270 & 0.278 & 0.286 & 0.295 & 0.301 & 0.305\end{array}$

$\begin{array}{lllllllllllllllllllllllllllll}M E A N & 24.867 & 24.493 & 25.417 & 27.116 & 26.347 & 25.243 & -0.014 & -0.017 & 0.004 & -0.014 & -0.015 & 0.004 & 4.520 & 4.518 & 4.518 & 4.519 & 4.513 & 4.513 & 1.649 & 1.633 & 1.608 & 1.591 & 1.589 & 1.595\end{array}$

Note: ARO = AROPE index; HRI = HR investment; CAP = Capital intensity; SIZ = Organizational size. Subscripts represent the moment of time $(t)$ 


\section{Table II. Matrix input to income inequality model.}

GIN1 GIN2 GIN3 GIN4 GIN5 GIN6 HRI1 HRI2 HRI3 HRI4 HRI5 HRI6 CAP1 CAP2 CAP3 CAP4 CAP5 CAP6 SIZ1 SIZ2 SIZ3 SIZ4 SIZ5 SIZ6 GIN1 3.241

GIN2 $2.544 \quad 2.399$

GIN3 $2.175 \quad 2.006 \quad 2.411$

GIN4 $1.539 \quad 1.365 \quad 2.225 \quad 2.895$

GIN5 $2.343 \quad 2.131 \quad 2.635 \quad 2.980 \quad 3.840$

$\begin{array}{lllllll}\text { GIN6 } & 3.043 & 2.597 & 2.953 & 3.095 & 4.102 & 5.240\end{array}$

HRI1 $-0.113 \quad-0.082 \quad-0.162-0.154 \quad-0.184 \quad-0.252 \quad 0.464$

$\begin{array}{llllllllll}\text { HRI2 } & -0.111 & -0.076 & -0.154 & -0.148 & -0.174 & -0.244 & 0.367 & 0.434\end{array}$

$\begin{array}{lllllllllll}\text { HRI3 } & -0.107 & -0.072 & -0.171 & -0.175 & -0.203 & -0.272 & 0.359 & 0.395 & 0.478\end{array}$

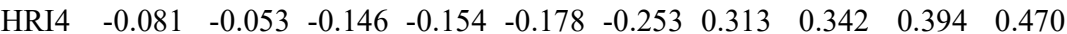

$\begin{array}{llllllllllllll}\text { HRI5 } & -0.097 & -0.063 & -0.137 & -0.131 & -0.165 & -0.243 & 0.261 & 0.279 & 0.317 & 0.365 & 0.459\end{array}$

$\begin{array}{llllllllllllll}\text { HRI6 } & -0.074 & -0.051 & -0.118 & -0.110 & -0.138 & -0.209 & 0.227 & 0.233 & 0.260 & 0.286 & 0.303 & 0.453\end{array}$

$\begin{array}{llllllllllllll}\text { CAP1 } & -0.091 & -0.074 & -0.068 & -0.042 & -0.069 & -0.070 & 0.111 & 0.097 & 0.111 & 0.106 & 0.091 & 0.083 & 0.375\end{array}$

$\begin{array}{llllllllllllllll}\text { CAP2 } & -0.086 & -0.068 & -0.057 & -0.025 & -0.053 & -0.049 & 0.115 & 0.108 & 0.123 & 0.116 & 0.100 & 0.087 & 0.364 & 0.408\end{array}$

$\begin{array}{llllllllllllllllll}\text { CAP3 } & -0.082 & -0.067 & -0.057 & -0.027 & -0.053 & -0.046 & 0.112 & 0.106 & 0.127 & 0.119 & 0.101 & 0.090 & 0.362 & 0.400 & 0.437\end{array}$

$\begin{array}{lllllllllllllllllll}\text { CAP4 } & -0.077 & -0.062 & -0.051 & -0.018 & -0.042 & -0.036 & 0.111 & 0.106 & 0.126 & 0.127 & 0.107 & 0.092 & 0.353 & 0.391 & 0.424 & 0.456\end{array}$

$\begin{array}{lllllllllllllllllllll}\text { CAP5 } & -0.071 & -0.063 & -0.047 & -0.014 & -0.046 & -0.039 & 0.113 & 0.107 & 0.127 & 0.124 & 0.107 & 0.095 & 0.341 & 0.376 & 0.405 & 0.427 & 0.461\end{array}$

$\begin{array}{llllllllllllllllllllll}\text { CAP6 } & -0.057 & -0.051 & -0.034 & -0.006 & -0.036 & -0.025 & 0.109 & 0.105 & 0.122 & 0.120 & 0.103 & 0.095 & 0.327 & 0.360 & 0.388 & 0.406 & 0.430 & 0.452\end{array}$

$\begin{array}{llllllllllllllllllllll}\text { SIZ1 } & -0.127 & -0.089 & -0.103 & -0.102 & -0.131 & -0.162 & 0.107 & 0.104 & 0.118 & 0.114 & 0.098 & 0.095 & 0.106 & 0.111 & 0.114 & 0.114 & 0.112 & 0.109 & 0.263\end{array}$

$\begin{array}{lllllllllllllllllllllllll}\text { SIZ2 } & -0.125 & -0.090 & -0.103 & -0.100 & -0.133 & -0.163 & 0.108 & 0.097 & 0.114 & 0.111 & 0.096 & 0.094 & 0.108 & 0.108 & 0.111 & 0.111 & 0.110 & 0.108 & 0.264 & 0.271 & & & \end{array}$

$\begin{array}{lllllllllllllllllllllllll}\text { SIZ3 } & -0.128 & -0.091 & -0.103 & -0.099 & -0.133 & -0.168 & 0.110 & 0.098 & 0.110 & 0.109 & 0.095 & 0.094 & 0.108 & 0.108 & 0.108 & 0.109 & 0.108 & 0.106 & 0.266 & 0.274 & 0.282\end{array}$

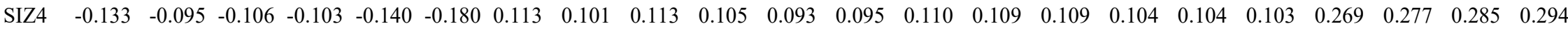

$\begin{array}{lllllllllllllllllllllllllllll}\text { SIZ5 } & -0.135 & -0.095 & -0.105 & -0.102 & -0.140 & -0.182 & 0.112 & 0.101 & 0.113 & 0.105 & 0.087 & 0.091 & 0.110 & 0.110 & 0.110 & 0.104 & 0.102 & 0.101 & 0.269 & 0.278 & 0.286 & 0.295 & 0.301\end{array}$

$\begin{array}{lllllllllllllllllllllllllll}\text { SIZ6 } & -0.136 & -0.095 & -0.105 & -0.102 & -0.141 & -0.183 & 0.111 & 0.101 & 0.113 & 0.105 & 0.087 & 0.087 & 0.110 & 0.110 & 0.110 & 0.105 & 0.103 & 0.099 & 0.270 & 0.278 & 0.286 & 0.295 & 0.301 & 0.305\end{array}$

$\begin{array}{lllllllllllllllllllllllllll}M E A N & 32.443 & 32.567 & 31.901 & 32.550 & 32.442 & 32.181 & -0.014 & -0.017 & -0.003 & -0.013 & -0.012 & 0.006 & 4.520 & 4.518 & 4.518 & 4.518 & 4.513 & 4.513 & 1.649 & 1.633 & 1.608 & 1.591 & 1.589 & 1.595\end{array}$

Note: GIN = Gini index; HRI = HR investment; CAP = Capital intensity; SIZ = Organizational size. Subscripts represent the moment of time $(t)$ 
